\title{
PENDEKATAN PEMBINAAN MORAL SISWA DI SMP NEGERI 4 KECAMATAN BANGUNTAPAN KABUPATEN BANTUL TAHUN PELAJARAN 2010/2011
}

\author{
Oleh: \\ Paiman* Esti Astuti* \\ Universitas Cokroaminoto Yogyakarta
}

\begin{abstract}
ABSTRAK
Penelitian ini bertujuan untuk mengetahui pendekatan pembinaan moral siswa di SMP Negeri 4 Kecamatan Banguntapan Kabupaten Bantul Tahun Pelajaran 2010/2011. Dengan demikian yang akan dipecahkan adalah pendekatan apa saja yang dilakukan sekolah dalam melaksanakan pembinaan moral kepada siswa SMP Negeri 4 Banguntapan Bantul. Penelitian ini merupakan penelitian deskriptif, pengumpulan data melalui wawancara dan dokumentasi, adapun subyek penelitian ini yaitu guru PKn dan Bimbingan Konseling.Analisis data menggunakan analisis kualitatif melalui tahap-tahap reducsion data, data disply, conclusions drawing and verifying, triangulasi dan kesimpulan. Hasil penelitian data menunjukkan, pembinaan moral di SMP Ngeri 4 Banguntapan Bantul dilaksanakan dengan menggunakan pendekatan informatif yaitu pembelajaran PKn dengan metode ceramah di kelas, pendekatan partisipatif yaitu studi kasus ,dan pendekatan eksperimental yaitu melalui kegiatan ekstrakulikuler. Sedangkan progam pembinaan yaitu pembinaan aspek kognitif misalnya studi kasus, pembinaan afektif afektif misalnya salam dan sikap didalam kelas, dan psikomotorik misalnya kegiatan ekstrakulikuler
\end{abstract}

Kata kunci : Pendekatan Pembinaan, Moral, Siswa SMP

\section{Pendahuluan}

Tujuan pendidikan adalah mencerdaskan kehidupan bangsa dan mengembangkan manusia Indonesia seutuhnya, yaitu manusia yang beriman, bertaqwaterhadap Tuhan Yang Maha Esa, berbudi pekerti luhur, memiliki pengetahuan dan ketrampilan, kesehatan jasmani dan rohani, kepribadian yang mantab, mandiri, serta tanggungjawab (Soenarjati, 2002: 42). Sebagaimana tertuang dalam Undang-Undang Pendidikan Nasional No. 20 Tahun 2003 tentang tujuan pendiddikan nasional yaitu "berkembangnya potensi peserta didik agar menjadi manusia yang beriman dan bertaqwa kepada Tuhan Yang Maha Esa, berakhlak mulia, sehat, berilmu , cakap, kreatiif, mandiri dan menjadi warga negara yang demokratis serta brtangungjawab (openlibrary.or: 2008). Berdasarkan pernyaraan diatas bahwa pendidikan tidak hanya 
berorientasi pada kecerdasan kognitif tetapi juga pengembangan karakter siswa, yaitu pengembangan moralitas siswa. Sekolah merupakan sarana pendidikan formal yangn sangat brpengaruh dalam perkembangan dan pertumbuhan moral peserta didik. Sebab lingkungan sekolah memiliki beberapa elemen pendidikan diantaranya guru sebagai salah satu unsur dalam proses pendidikan.

Guru merupakan figur yang menjadi panutan peserta didik, sehingga tingkah laku, sikap, dan tindakan yang biasa dilakukannya menjadi fokus perhatian siswa dalam bertindak. Disinilah kemudian peranan guru menjadi sangat penting dalam keberhasilan penanaman dan pelaksanaan pendiddikan moral. Merosotnya nilai moral akhir-akhir ini di kalangan pelajar, seperti kenakalan siswa menimbulkan permasalahan pendidikan terutama dalam hal menentukan metode pendekatan pembinaan moral kepada peserta didik.Hal ini disebabkan siswa tidak bisa diberikan pendidikan denagn metode aturan keras. Sebab jika diberlakukan aturan keras maka akan terjadi banyak siswa justru semakin melawan dan tidak mematuhi aturan yang sudah ditetapkan sekolah. Kekhawatiran inilah yang menyebabkan sekoalh mencari dan mengubah pembinaan pendidikan moral kepada siswa melalui pendekatan-pendekatan khusus.

Pembinaan denagn penanaman nilai-nilai moral kepasa siswa sangat diperlukan agar siswa memilki rasa tangungjawab atas tindakan yang dilakukannya.Pembinaan dimaksudkan untuk memberikan pemahaman, perhatian, pertimbangan, dan tidakan agar siswa memiliki kecerdasan emosi dan perkembangan secara moral untuk membantu pembentukan karakter yang baik dan mandiri. Dengan demikian perlu dilakukan perhatian lebih terfokus mennegnai tugas serta kewajiban sekolah dalam membian moral terutama pembinaan moral kepada siswa, karena pelaksanaan pembinaan moral juga dapat memberikan gambaran yang lebih komprehensif tentang cara sekolah menangani masalah siswa. Adapun subyek dalam penelitian ini adalah guru PKn dan guru Bimbingan Konseling SMP Negeri 4 Banguntapan Bantul. Berdasarkan uraian diatas penulis tertarik untuk meneliti pendekatan pembinaan moral siswa yang dilakukan guru dengan judul penelitian pendekatan pembinaan moral siswa di SMP Negeri 4 Banguntapan Bantul Tahun Pelajaran 2010/2011 


\section{Landasan Teori}

Pengertian pembinaan moral adalah suatu tindakan untuk menanamkan nilai-nilai moral, mendidik, membina, membangun akhlak serta perilaku seseorang agar orang yang bersangkutan terbiasa mengenal, ,memahami serta menghayati sifat-sifat baik atau aturan-aturan moral yang mencakup aspek kognitif, afektif, dan psikomotorik sehingga orang tersebut bisa bersikap dan dengan niali-nilai moral (Mangunharjo, 1986: 20).

\section{Metode}

Penelitian ini menggunakan wawancara dan dokomentasi dalam teknik pengumpulan data.Dalam penelitian ini peneliti menggunakan metode wawancara bebas, agar responden secara bebas dan terbuka menjawab pertanyaan. Adapun untuk analisis data menggunakan analisis kualitatif melalui tahap-tahap reducsion data yang mencakup kegiatan mengikhtiarkan hasil pengumpulan data selengnkap mungkin, data displyyang mencakup kegiatan mengorganisasi data dalam bentuk tertentu sehinga terlihat sosoknya secara lebih utuh, conclusions drawing and verifyingadalah penarikan kesimpulan berdasarkan analisi data penelitian, dan triangulasi untuk mengkroscek kebenaran hasil penelitian. Menurut Lexy J Moleong (2004: 29), "Triangulasi adalah pemeriksaan keabsahan data yang memanfaatkan sesuatu yang lain di luar data itu. Triangulasi dengan sumber berarti membandingkan dan mengecek balik derajat kepercayaan suatu informasi yang diperoleh melalui waktu dan alat yang berbeda dalam penelitian kualitatif.

\section{Tinjauan Tentang Moral}

Moral berasal dari bahasa latin mores yang berarti adat istiadat. Soenarjati \& Cholisin (1989: 25) menyatakan pendapatnya bahwa moral dapat diartikan sebagai kebiasaan dalam bertingkah laku yang baik. Moral menurut Franz Magnis Suseno (1989: 25) tidak hanya mengenai baik buruknya sebagai manusia tetapi juga sebagai tolak ukur untuk menentukan betul salahnya sikap dan tindakan manusia dilihat dari segi baik buruknya sebagai manusia bukan sebagai pelaku peran tertentu. Moral yaitu sebagai sesuatu yang terkait dengan menentukan benar salahnya suatu tingkah laku (Cheppy Hari Cahyono, 1995: 221). Moral secara lebih komprehensif, yaitu:

1) Moral sebagai perangkat ide-ide tentang tingkah laku hidup dengan warna dasar tertentu yang dipegang oleh sekelompok manusia di dalam lingkungan tertentu. 
2) Moral adalah ajaran tentang tingkah laku hidup yang baik berdasarkan pandangan hidup atau agama tertentu.

3) Moral sebagai tingkah laku hidup manusia yang mendasarkan pada kesadaran bahwa ia terikat oleh keharusan yang mencapai yang baik sesuai dengan nilai norma yang berlaku dalam lingkungannya (Wila Huky, 2000: 1).

Moral memuat dua segi yang berbeda yakni segi batiniah dan segi lahiriyah. Orang yang baik adalah orang yang memiliki sikap batin yang baik dan melakukan perbuatan-perbuatan yang baik pula, akan tetapi sikap batin yang baik baru terlihat orang lain setelah terwujud dalam perbuatan lahiriyah yang baik pula. Moral hanya dapat diukur secara tepat apabila segi lahiriyah dan batiniah tersebut diperhatikan. Orang hanya dapat dilihat secara tepat apabila hati maupun perbuatannya dilakukan secara bersama. Moral merupakan sesuatu yang melekat pada hakekat manusia. Berdasarkan pendapat di atas dapat disimpulkan bahwa moral dianggap sebagai kebiasaan dalam bertingkah laku tetapi juga sebagai tolak ukur menentukan betul salahnya sikap dan tindakan manusia.

\section{Materi pembinaan moral}

Materi pembinaan moral menyangkut nilai-nilai moral yang berkaitan dengan pribadi manusia. Nilai moral ini secara ringkas mempunyai cirri-ciri sebagai berikut:

1) Berkaitan dengan tanggung jawab

Menandai nilai moral berkaitan dengan pribadi manusia yang tanggungjawab. Nilai-nilai moral mengakibatkan bahwa seseorang bersalah atau tidak bersalah, karena ia tanggungjawab. Dalam nilai moral kebebasan dan bertanggungajawab merupakan syarat mutlak.

2) Berkaitan dengan nilai-nilai nurani

Mewujudkan nilai-nilai moral merupakan himbauan dari hati nurani. Salah satu cirri khas nilai moral adalah bahwa hanya nilai ini yang menimbulkan suara dari hati nurani yang menuduh kita bila meremehkan atau menentang nilai-nilai moral dan memuji bila mewujudkan nilai-nilai moral. Suara hati merupakan penghayatan tentang baik buruk berhubungan dengan tingkah laku konkrit seseorang dan suara hati merupakan kesadaran moral seseorang dalam situasi konkrit. 
3) Mewajibkan setiap orang menerima secara mutlak.

Nilai-nilai moral mewajibkan setiap orang untuk menerimanya secara mutlak. Suka atau tidak suka orang sudah sepatutnya harus mewujudkan serta mengakui keberadaan nilai-nilai moral, karena tidak mungkin seseorang dapat memilih beberapa nilai moral dan menolak nilai moral lainnya. Setiap orang harus menerima semuanya, orang tidak mempunyai atau mengakui nilai moral mempunyai cacat sebagai manusia (Bertens, 1993: 143-147).

\section{Pembahasan}

Pendekatan yang dilakukan guru dalam melaksanakan pembinaan moral antara lain sebagai berikut:

\section{Pendekatan Informatif}

Pendekatan informatif yaitu menjalankan progam dengan menyampikan informasi kepada siswa.Pendekatan ini biasanya menggunakan merode pembinaan yang diisi dengan ceramah atau kuliah oleh beberapa pembicara mengenai hal yang diperlukan peserta berupa penjelasan atau penyampaian pertanyaan yang belum dipahami peserta. Seperti yang dilakukan guru PKn SMP Negeri 4 Banguntapan Bantul dengan kegiatan pembelajaran di kelas yaitu kegiatan keagamaan dengan metode ceramah sebagai berikut:

a. Penyampaian materi pelajaran kepada siswa di kelas. Penyampaian materi pelajaran kepada siswa di kelas menyangkut pembinaan yang berhubungan dengan kecerdasan atau intelektualitas yang mengarah pada aspek kognitif, berupa kemampuan memecahkan masalah, berpikir untuk mencari solusi.Biasanya guru sedikit memberikan ulasan materi kemudian memberikan pertanyaan kepasa siswa atau siswa menyampaikan pendapatnya.Pembinaan kognitif disini juga dilakukan guru dengan memberikan contoh kasus yang harus dianalisa atau dibahas siswa.Tujuannya adalah untuk melihat kemampuan siswa memahami serta berpikir dalam mengatasi persoalan sosial serta membuat keputusan. Seperti yang disampaiakn ibu Sasita Dewayani, S.Pd berikut ini: "Ya, usaha yang kita lakukan tersebut menggunakan pendekatan yang sesuai dengan karakter siswa, permasalahan yang dialami, yang dapat diterima siswa dengan mudah dan cepat. Seperti memberikan bimbingan dan nasehat-nasehat melalui pembelajaran dikelas, dengan cara menyisipkannya dalam pemberian materi kepada siswa misalnya dengan ceramah. Kemudian memberikan kesempatan kepada siswa untuk menyampaikan pertanyaan ataupun mengungkapkan permasalahannya.Dengan 
metode ini pula guru dapat melihat apakah bahasan menganai nilai-nilai moral yangn terdapat dalam materi dapat diterima siswa.Dengan begini secara tidak langsung siswa belajar bagaimana menyikapi suatu permasalahan dengan hati nuraninya dan dikendalikan melalui setiap tindakannya".

b. Penanaman moral yang baik melalui contoh tokoh dan peristiwa. Pemberian gambaran tentang pembinaan moral dengan mengambil contoh tokoh dengan tujuan agar siswa dapat mengambil contoh keteladanan dari tokoh tersebut, eperti yang dicontohkan guru PKn .

\section{Pendekatan Partisipasi}

Pendekatan partisipasi banyak melibatkan peserta, misalnya diskusi kelompok. Memecahkan suatu kasus, pembinaan lebih merupakan situasi belajar bersama. Di SMP Negeri 4 Banguntapan pendekatan partisipasi dilakukan guru dengan pamecahan kasus melalui diskusi kelompok. Seperti yang disampaikan oleh guru PKn sebagai berikut: "Dan untuk merangsang kreatifitas siswa untuk peduli terhadap persoalan sosial dalam masyarakat melalui studi kasus atau pemecahan masalah dengan cara diskusi kelompok". Pelaksanaan pembelajaran dengan metode studi kasus, dilakukan dengan membuat diskusi kelompok.Setelah selesai dalam diskusi kelompok, siswa mempresentasikan hasil diskusi tersebut didepan kelas.Sedangkan kelompok yang belum mendapat giliran untuk mempresentasikan hasil diskusi, mendengarkan dan mengajukan pertanyaan tentang hal yang belum diketahui ataupun memberikan tanggapan hasil diskusi kelompok yang dipresentasikan. Melalui metode ini diharapkan siswa aktif dan kreatif memberi solusi atas kasus yang dihadapi, dengan cara ni pula melatih siswa untuk saling bekerjasama, saling menghormati pendapat orang lain, serta menerima dengan terbuka kritik dan saran teman ataupun guru. Sehingga metode pengajaran nilai-nilai moral dan metode mengajar denagn nilai-nilai moral merupakan kesatuan yang tidak bisa dipisahkan dalam penerapannya. Metode ini mampu menciptakan suasana kelas yang diharapkan bisa membentuk kerpbadian siswa lebih bermoral. Melalui diskusi kelompok denagn materi studi kasus diharapkan siswa memiliki ide atau gagasan yang dapat membangun daya kreatifitas berpikir termasuk meningkatkan kepedulian terhadap persoalan-persoalan sosial

\section{Pendekatan Eksperimental}

Pendekatan eksperimental mennghubungkan langsung peserta dengan pengalaman pribadi dan mempergunakan metode yang mendukung. Dengan kata lain metode ini melaksanakan praktek langsung terhadap apa yang telah diajarkan atau disampaikan. Mengisi kegiatan dengan 
ha-hal yang positif dalam manggali atau mengembangkan bakat dan potensi diri.Seperti kegiatan ekstrakulikuler atau kegiatan lainnya, misalnya kegiatan bakti sosial, drumband, voli, karya ilmiah.

Di SMP Negeri 4 Banguntapan kegiatan ekstrakulikuler diadakan setiap seminggu sekali.Pembagian kegiatan diatur berdasarkan jadwal.Pembagian jadwal sekolah ekstrakulikuler sebagai berikut:

a. Senin : Drumband

b. Selasa : Menari dan Teater

c. Rabu : Karate

d. Jum'at : Gendhing Gamelan

Siswa antusias mengikuti kegiatan tersebut, namun sarana gamelan yang tidak lengkap membuat siswa harus bergantian menunggu untuk dapat menggunakannya.Sama halnya dengan fasilitas karate seperti tidak ada matras dan sarung tangan.

\section{Faktor penghambat pembinaan moral}

Faktor penghambat, adalah beberapa unsur yang mempersulit dilaksanakannya pembinaan moral siswa di sekolah, diantaranya: latar belakang siswa serta sarana dan prasarana yang kurang lengkap dan tidak memadai.

1. Latar belakang siswa

Latar Belakang siswa menjadi salah satu faktor penghambat pembinaan moral. Setiap siswa memiliki latar belakang hidup yang berbeda-beda. Sehingga dibutuhkan kesabaran guru dan semua komponen untuk mengatasinya.

2. Sarana dan prasarana

Selain itu sarana dan prasarana yang kurang lengkap menjadi penghambat keberhasilan pembinaan moral di SMP 4 Banguntapan. Seperti kurangnya fasilitas untuk kegiatan ekstrakurikuler. Namun hambatan tersebut dapat diatasi oleh guru dengan memberikan peringatan bagi siswa yang melanggar tata tertib. Guru di sini tidak sekedar mengajar tetapi juga memantau siswa, baik sikap dan tingkah lakunya di sekolah. Pro aktif dengan orang tua dalam pembinaan moral siswa. Saling memberikan informasi terkait sikap dan perilaku siswa di sekolah dan di rumah. 


\section{Kesimpulan}

Berdasarkan hasil penelitian dan pembahasan tentang pendekatan pembinaan moral siswa SMP Negeri 4 Banguntapan Bantul Tahun Pelajaran 2010/2011 penulis dapat menyimpulkan sebagai berikut:

Pendekatan yang digunakan guru dalam melaksanakan pembinaan moral siswa SMP Negeri 4 Banguntapan Bantul adalah sebagai berikut:

1. Pendekatan Informatif, seperti dilakukan guru PKn SMP Negeri 4 Banguntapan Bantul dengan kegiatan pembelajaran di kelas. Kegiatan keagamaan yaitu ceramah. Pengampaian materi pelajaran kepada siswa di kelas penanaman moral yang baik melalui contoh tokoh dan peristiwa.

2. Pendekatan Partisipasi, dilakukan guru PKn SMP Negeri 4 Banguntapan Bantul dengan pemecahan kasus melalui diskusi kelas. Pendekatan ini mampu menciptakan susana kelas yang diharapkan bisa membentuk kepribadian siswa lebih bermoral.

3. Pendekatan Eksperimental di SMP Negeri 4 Banguntapan Bantul, kegiatan ekstrakulikuler di sekolah diadakan setiap semingu sekali. Pembagian kegiatan diatur berdasarkan jadwal, misalnya Senin drumband, Selasa ekstrakulikuler menari dan teater, Rabu ekstrakulikuler karate, dan Jum'at gendhing gamelan.

\section{Saran}

1. Perlu adanya pengembangan metode dalam melaksanakan pembinaan moral kepada siswa, sehingga siswa lebih mudah untuk menerima maksud dan arah dari pembinaan moral.

2. Perlunya penambahan sran dan prasaran, khususnya untuk kegiatan ekstrakulikuler yang banyak mempraktekan teori yang diberikan.

3. Perlunya pemahaman guru terhadap kondisi siswa serta latar belakang siswa secara bijak.

4. Perlunya dilakukan secara intensif pembinaan moral di sekolah, mengingat siswa adalah genarasi penerus bangsa, agar terwujud generasi penerus yang berakhlak, kreatif, cerdas, dan bertanggungjawab. 


\section{Daftar Pustaka}

Anonim. (2007). www.goegle.com. Pembinaan Moral ditampilkan 15 Desember 2011.

Bertens. (1993). Etika. Jakarta: Gramedia.

Lexy, J. Moleong. (2001). Metodologi Penelitian Kualitatif. Bandung: Remaja Karya.

Mangunhardjono. (1986). Pembinaan Arti dan Metodenya. Yogyakarta: Kanisius.

Soenarjati \& Cholisin. (2002). Dasar-Dasar Pendidikan Moral Dalam Kurikulum Sekolah. Cetakan ke-V. Yogyakarta: Goeboek Indonesia. 